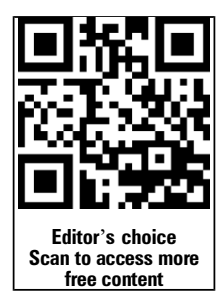

- Additional material is published online only. To view please visit the journal online (http://dx.doi.org/10.1136/ thoraxjnl-2014-206161).

For numbered affiliations see end of article.

\section{Correspondence to} Dr Mariëlle W Pijnenburg, Division Paediatric Respiratory Medicine, Erasmus University Medical Centre-Sophia Children's Hospital, P.O. Box 2060, Rotterdam 3000 CB , the Netherlands; m.pijnenburg@erasmusmc.nl

Received 13 August 2014 Revised 11 February 2015 Accepted 17 February 2015 Published Online First 30 March 2015

\title{
Monitoring strategies in children with asthma: a randomised controlled trial
}

Sandra Voorend-van Bergen, ${ }^{1}$ Anja A Vaessen-Verberne, ${ }^{2}$ Hein J Brackel, ${ }^{3}$
Anneke M Landstra, ${ }^{4}$ Norbert J van den Berg, ${ }^{5}$ Wim C Hop, ${ }^{6}$ Johan C de Jongste, ${ }^{1}$
Peter J Merkus, ${ }^{7}$ Mariëlle W Pijnenburg ${ }^{1}$ Department of Paediatrics,

ABSTRACT

Background Asthma guidelines recommend

monitoring of asthma control. However, in a substantial proportion of children, asthma is poorly controlled and the best monitoring strategy is not known.

Objectives We studied two monitoring strategies for their ability to improve asthma outcomes in comparison with standard care (SC): web-based monthly monitoring with the (Childhood) Asthma Control Test (ACT or

$\mathrm{C}-\mathrm{ACT}$ ) and 4-monthly monitoring of $\mathrm{FE}_{\mathrm{NO}}$.

Methods In this randomised controlled, partly blinded, parallel group multicentre trial with a 1-year follow-up, children aged 4-18 years with a doctor's diagnosis of asthma treated in seven hospitals were randomised to one of the three groups. In the web group, treatment was adapted according to ACT obtained via a website at 1-month intervals; in the $\mathrm{FE}_{\mathrm{NO}}$ group according to $\mathrm{ACT}$ and $\mathrm{FE}_{\mathrm{NO}}$, and in the $\mathrm{SC}$ group according to the $\mathrm{ACT}$ at 4-monthly visits. The primary endpoint was the change from baseline in the proportion of symptom-free days (SFD).

Results Two-hundred and eighty children (mean age 10.4 years, $66 \%$ boys) were included; 268 completed the study. Mean changes from baseline in SFD were similar between the groups: $-2.1 \%$ (web group, $n=90$ ), $+8.9 \%$ ( $\mathrm{FE}_{\text {No }}$ group, $\mathrm{n}=91$ ) versus $0.15 \%(\mathrm{SC}, \mathrm{n}=87$ ), $p=0.15$ and $p=0.78$. Daily dose of inhaled

corticosteroids (ICS) decreased more in the web-based group compared with both other groups $(-200 \mu \mathrm{g} / \mathrm{day}$, $p<0.01$ ), while ACT and SFD remained similar.

Conclusions The change from baseline in SFD did not differ between monitoring strategies. With web-based ACT monitoring, ICS could be reduced substantially while control was maintained.

Trial registration number NTR 1995.

\section{SLinked}

- http://dx.doi.org/10.1136/ thoraxjnl-2015-206898

\section{CrossMark}

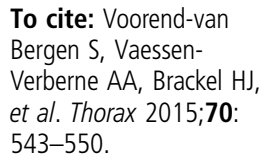

\section{INTRODUCTION}

In a substantial proportion of children with asthma, control is not achieved. ${ }^{1-3}$ Guidelines pay little attention to monitoring strategies. The Asthma Control Test (ACT) and the Childhood ACT (C-ACT) for children aged $<12$ years are simple, validated tools to assess asthma control. ${ }^{4}{ }^{5}$ Web-based ACT monitoring of asthma control has the potential to standardise the assessment of asthma control, increase awareness of asthma and improve adherence. The fraction of nitric oxide in exhaled air $\left(\mathrm{FE}_{\mathrm{NO}}\right)$ is a non-invasive biomarker of eosinophilic airway inflammation ${ }^{6}$ but the benefits

\section{Key messages}

What is the key question?

- Does web-based monthly monitoring with the (Childhood) Asthma Control Test or 4-monthly monitoring of $\mathrm{FE}_{\mathrm{NO}}$ improve asthma outcomes in comparison with standard care?

\section{What is the bottom line?}

- This randomised controlled trial shows that neither monthly web-based monitoring with the Asthma Control Test nor regular measurement of $\mathrm{FE}_{\mathrm{NO}}$ increased symptom-free days in asthmatic children.

\section{Why read on?}

- Despite the emphasis of asthma guidelines on monitoring childhood asthma, the best way of how to do this is still unknown; this study evaluates three monitoring strategies.

of $\mathrm{FE}_{\mathrm{NO}}$ for asthma monitoring are not yet clear. ${ }^{7}$ In the present study, we evaluated the possible benefits of web-based monitoring with monthly ACT measurements and adapting the treatment based on 4-monthly $\mathrm{FE}_{\mathrm{NO}}$ measurements. We hypothesised that both strategies are superior to standard care (SC).

\section{METHODS}

The 'Better Asthma Treatment: Monitoring with ACT and Nitric oxide' study was a multicentre, prospective, partly blinded, parallel-group, three-arm randomised controlled superiority trial on monitoring strategies in asthmatic children with a follow-up of 1 year (trial number NTR 1995).

\section{Patients}

Children aged 4-18 years, with atopic asthma based on clinical symptoms, a previous bronchodilator response of $>9 \%$ increase in $\mathrm{FEV}_{1}$ of predicted $\left(\mathrm{FEV}_{1} \%\right)$ and/or previous airway hyperresponsiveness (AHR) to methacholine were recruited by their own paediatrician from general hospitals $(n=5)$ and tertiary referral centres $(n=2)$ in the Netherlands from February 2010 to November 2011. Atopy was defined as a radioallergosorbent test class 2 or higher for at least one airborne allergen. Patients had been using inhaled corticosteroids (ICS) for at least 3 months before 
the study. Exclusion criteria were active smoking, pulmonary diseases other than asthma, recent ( $<1$ year) or multiple admissions to an intensive care unit for asthma, inability to perform $\mathrm{FE}_{\mathrm{NO}}$ measurements and/or the use of omalizumab. All parents and children aged $\geq 12$ years gave written informed consent.

\section{Study design}

Patients were screened for eligibility by the physician and enrolled by the local investigator, who collected data on subject characteristics, $\mathrm{FE}_{\mathrm{NO}}$ and ACT score (visit 0). After a 4-week run-in period, children were automatically and randomly allocated to one of the three groups by a randomisation programme on the study website, in a 1:1:1 ratio, stratified for age $(<12$ or $\geq 12$ years), centre and dose of ICS $(<400$ or $\geq 400 \mu \mathrm{g}$ budesonide or equivalent daily dose; figure 1 ). Children who completed $<50 \%$ of the diaries in the run-in period were withdrawn from the study. In the web group, treatment was adapted monthly according to the web-based ACT score, while in the $\mathrm{FE}_{\mathrm{NO}}$ group, treatment was adapted to $\mathrm{FE}_{\mathrm{NO}}$ and ACT score at clinic visits every 4 months (figure 2 ). In the $\mathrm{FE}_{\mathrm{NO}}$ group, we used two cut-off points for decreasing $(<25 \mathrm{ppb})$ or increasing $(>50 \mathrm{ppb})$ treatment. In the SC group, the ACT score during clinic visits directed treatment (figure 2). In case of ACT $\geq 20$ step down was advised, but the physician was allowed to leave treatment unchanged. The study duration was 12 months, with visits at 4-month intervals and one baseline visit 4 weeks prior to randomisation. In addition, children randomised to the web group were asked to fill in an ACT every month on a website that provided a treatment advice by email by the researcher or asthma nurse within three working days. In the $\mathrm{FE}_{\mathrm{NO}}$ and $\mathrm{SC}$ groups, treatment changes were possible at the 4-monthly study visits; in the web group, treatment could be changed monthly. Patients were not blinded to randomisation group. The treating physicians were blinded to randomisation group, $\mathrm{FE}_{\mathrm{NO}}$ and ACT. The local investigators, unblinded to $\mathrm{ACT}$ and $\mathrm{FE}_{\mathrm{NO}}$, provided the physicians with treatment advice based on the study algorithms and on the treatment plan (figure 2; see online supplementary table S1). Physicians could deviate from this advice for documented clinical reasons only. The primary endpoint was change from baseline of the proportion of symptom-free days (SFD); secondary endpoints were changes from baseline of ACT, daily symptom score, daily bronchodilator doses, daily ICS dose, asthma-related quality of life, dose of methacholine causing a 20\% fall in $\mathrm{FEV}_{1}$ (PD20), FVC, FEV and maximal expiratory flow at $25 \%$ of vital capacity (MEF25) and exacerbations during the study. The final ICS dose was the dose the patient was on immediately prior to the final visit.

\section{Symptom-free days}

SFDs were defined as days without daytime or night-time symptoms and were obtained from a web-based diary which recorded daytime and night-time symptoms, limitation in activity and use of reliever medication. ${ }^{8}$ Diary data were collected twice daily during the 4 -week run-in period, during the 2 weeks preceding each visit and during 4 weeks preceding the final visit (figure 1). Each symptom item had four response levels $(0=$ asymptomatic to 3 =highly symptomatic); the maximal daily diary score was 21. Diaries were automatically date-stamped and time-stamped and could be filled in until 5 days after the date. Participants received a reminder by email once daily.

\section{Asthma Control Test}

We used the Dutch, translated and linguistically validated version of the ACT (MAPI-research institute, Lyon, France) in children from the age of 12 years, and the C-ACT for children aged 4-11 years. ${ }^{4}$

\section{Lung function and $\mathrm{FE}_{\mathrm{NO}}$}

FVC, FEV $_{1}$ and MEF25 were assessed using an electronic spirometer (Masterscreen, Jaeger, Würzburg, Germany) and expressed as percentage predicted or $\mathrm{z}$-score according to GLI2012. ${ }^{9}$ The provocative dose of methacholine that produced a 20\% fall in FEV1 (PD20) was measured using the dosimeter method (see details in the online supplement). $\mathrm{FE}_{\mathrm{NO}}$ was measured online on the NIOX chemiluminescence analyzer or NIOX MINO (Aerocrine, Stockholm, Sweden) according to guidelines. $^{10}$

\section{Quality of life}

In children aged 12 years and older, asthma-related quality of life was measured with the 23-item self-reported Dutch validated version of the Paediatric Asthma-Related Quality of Life Questionnaire (PAQLQ) for children ${ }^{11} 12$ and expressed as overall asthma-related quality of life. In children aged below 12 years, we used the Paediatric Asthma-Related Caregiver Quality of Life Questionnaire (PACQLQ). ${ }^{11}$ In both tests, the maximal score of 7 indicates optimal quality of life.

\section{Statistical analysis}

Because there were two major comparisons in this study (Web vs $\mathrm{SC}$ and $\mathrm{FE}_{\mathrm{NO}}$ vs $\mathrm{SC}$ ), the alpha level was set at two-sided 0.025 . For all other comparisons, the limit of significance was set at two-sided $\mathrm{p}=0.05$. The power of the study was calculated to detect differences between the experimental arms and SC, based on $18 \%$ increase in the mean percentage of SFD (corresponding to 2.5 extra SFD in 2 weeks time) with $80 \%$ probability in 87 children per group. ${ }^{13}$ Baseline data were compared using the $\chi^{2}$ test for categorical data or the Kruskal-Wallis test for continuous data. Diary data were evaluated using repeated measurements analysis of variance with baseline data during run-in used as covariates. The significance of differences of other continuous endpoints was determined using analysis of covariance (adjusted for baseline). For within-group comparisons, we used paired t tests. The statistical analysis of PD20 is described in the online supplement. Data were analysed with SPSS for Windows, V.21.0.

\section{RESULTS}

Of the 481 children who were eligible for participation, 201 refused, mostly because they were too busy with school (figure 3). Eight children could not be randomised because of nonadherence. Thus, 272 were included: 91 in the web group, 92 in the $\mathrm{FE}_{\mathrm{NO}}$ group and 89 in the $\mathrm{SC}$ group. Baseline characteristics are given in table 1 . The drop-out rate during the trial was small in both groups (web: $n=1, \mathrm{FE}_{\mathrm{NO}}: \mathrm{n}=1 ; \mathrm{SC}: \mathrm{n}=2$ ), all related to non-compliance. The proportions of children with well-controlled asthma (ACT $\geq 20)$ at the start of the study were 0.77 for the web group, 0.73 for the $\mathrm{FE}_{\mathrm{NO}}$ group and 0.76 for the SC group (NS). Baseline ACT was significantly higher in the web group compared with the $\mathrm{FE}_{\mathrm{NO}}$ group, but in both intervention groups, ACT was not significantly different from the SC group.

\section{Symptom-free days}

The change in the proportion of SFD between visits 1 and 4 did not differ significantly between the groups (SC vs web group: $0.07(\mathrm{p}=0.2)$; SC vs $\left.\mathrm{FE}_{\mathrm{NO}}: 0.01(\mathrm{p}=0.8)\right)$. A small but significant within-group change was seen both in the $\mathrm{FE}_{\mathrm{NO}}$ group and 
Figure 1 Study design. At visit 1, children were randomly allocated to one of the three study groups.

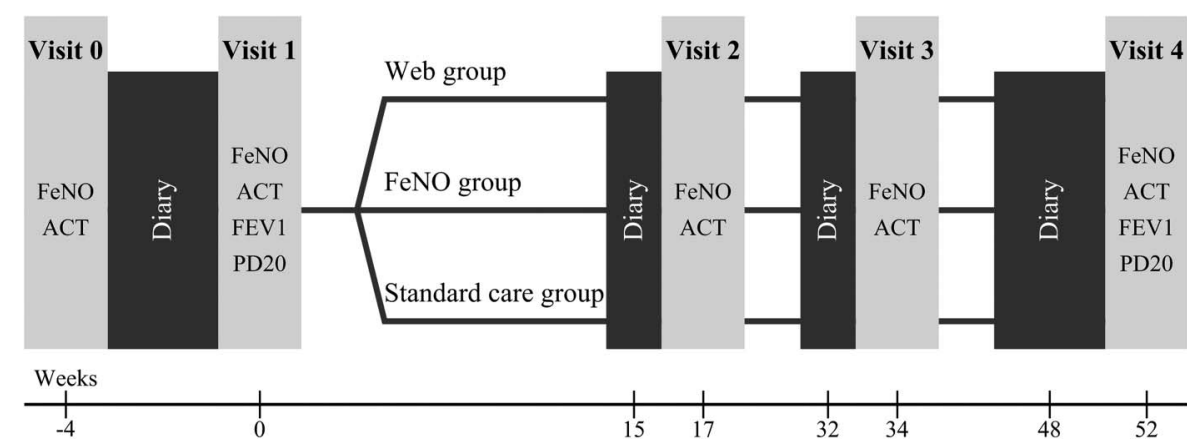

in the SC group: 0.53 to $0.62(\mathrm{p}=0.01)$ and 0.54 to 0.61 $(\mathrm{p}=0.04)$, respectively (table 2$)$. Longitudinal data are presented in the online supplement.

\section{ACT scores}

The $\mathrm{FE}_{\mathrm{NO}}$ group showed a 1.7-point improvement in ACT that was higher than in the SC group ( 0.4 points) $(p=0.02)$. This change in (C-) ACT points was determined by the findings in the young children who used the C-ACT: 1.84 points $(p<0.01)$, while no such change was present in children who used the ACT (-0.28 points, $p=0.7)$. No significant change in the ACT was seen in the web group.

\section{Symptom scores, limitation of activities and use of $\beta-2$ agonists}

The change between visits 1 and 4 in mean daily symptom scores and the use of $\beta-2$ agonists did not differ between the SC and the web group or between the $\mathrm{SC}$ and the $\mathrm{FE}_{\mathrm{NO}}$ group (table 2). The mean daily symptom score improved within the $\mathrm{FE}_{\mathrm{NO}}$ group only $(-0.40, \mathrm{p}=0.01)$.

\section{Exacerbations}

There were 42 exacerbations during the study: 7 hospital admissions and 35 systemic steroid courses. The distribution over the groups was similar: 10,14 and 17 exacerbations in the web, $\mathrm{FE}_{\mathrm{NO}}$ and $\mathrm{SC}$ groups, respectively. The exacerbation number per patient per year was 0.11 (web group), 0.15 ( $\mathrm{FE}_{\mathrm{NO}}$ group), 0.20 (SC); differences were not significant.

\section{Lung function and $\mathrm{FE}_{\mathrm{NO}}$}

Mean changes from baseline in lung function and PD20 did not differ between groups (table 2). $\mathrm{FEV}_{1}$ and FVC increased significantly in both the $\mathrm{FE}_{\mathrm{NO}}$ and the SC group. Data on PD20 are presented in the online supplement. Within all groups, a significant increase in $\mathrm{FE}_{\mathrm{NO}}$ was found. The geometric means of $\mathrm{FE}_{\mathrm{NO}}$ increased by a factor of 1.6 in the web group, 1.4 in the $\mathrm{FE}_{\mathrm{NO}}$ group (both $\left.\mathrm{p}<0.01\right)$ and 1.2 in the $\mathrm{SC}$ group $(\mathrm{p}=0.04)$. Changes in $\mathrm{FE}_{\mathrm{NO}}$ during the study were significantly different between the SC and the web group, but not between the SC and the $\mathrm{FE}_{\mathrm{NO}}$ group. The ratios of geometric means, adjusted for baseline, were $1.3(\mathrm{p}<0.01)$ for the web group and 1.1 for the $\mathrm{FE}_{\mathrm{NO}}$ group $(\mathrm{p}=0.24)$ as compared with the $\mathrm{SC}$ group.

\section{Treatment levels and ICS doses}

At visit 1 , median ICS doses, long-acting $\beta$-agonist use and leukotriene receptor antagonist use did not differ between the study groups (table 1). In all groups, medication could be reduced. Medication could be reduced by $74 \%$ in children in the web group, $52 \%$ in the $\mathrm{FE}_{\mathrm{NO}}$ group and $45 \%$ in the SC group. The reduction was significantly larger in the web group compared with the SC group $(\mathrm{p}<0.001)$, but not in the $\mathrm{FE}_{\mathrm{NO}}$ group. The mean daily ICS dose was reduced by $201 \mu \mathrm{g}$ in the web group, $107 \mu \mathrm{g}$ in the $\mathrm{FE}_{\mathrm{NO}}$ group and $54 \mu \mathrm{g}$ in the SC group (both $\mathrm{p}<0.01$, table 2 ). Longitudinal data are presented in the online supplement.

\section{Quality of life}

In all groups, there were no significant changes in PAQLQ or PACQLQ scores, and mean changes from baseline did not differ between the groups (table 2).

\section{Decision making}

For the $\mathrm{FE}_{\mathrm{NO}}$ group and the $\mathrm{SC}$ group, we determined whether the treatment advice would have been different if patients had been allocated to the other study group, which was the case in $62 \%$ of all decisions.

\section{Adherence of patients and physicians}

The completion rates of the web-based diary cards, web-based ACTs, medication adherence and physicians' adherence to the protocol were excellent (see online supplement).

In online supplementary table S2, absolute values of secondary outcomes at the start and end of the study are presented.

\section{DISCUSSION}

We compared web-based $\mathrm{ACT}$ monitoring and $\mathrm{FE}_{\mathrm{NO}}$ monitoring with SC in children with allergic asthma. After 1 year, both strategies had not improved the number of SFD more than SC. Monthly web-based ACTs resulted in a clinically relevant decrease of ICS dose, while maintaining asthma control. Children in the $\mathrm{FE}_{\mathrm{NO}}$ group showed a modest increase in (C-) ACT score as compared with SC, with similar average medication levels. This increase in asthma control was only found in the children under the age of 12 years who used the C-ACT. Other measures of asthma control did not improve as a result of $\mathrm{FE}_{\mathrm{NO}}$ monitoring.

The ACT is increasingly used in asthma management and the Global Initiative for Asthma guidelines state that 'the value of ACT and C-ACT in clinical use has yet to be demonstrated but will likely become evident in coming years. ${ }^{2}$ This study does not support the clinical use of monthly ACT measurements as our primary outcome did not improve. However, we were able to decrease the dose of ICS significantly only in the web group, and this suggests that ACT-guided step-down of treatment is feasible and safe, and reduces overtreatment. By administering the ACT once monthly, a fast response to changes in asthma control is possible. The higher frequency of healthcare contacts may explain part of the success of this approach. Web-based monitoring is a promising new strategy in the care for patients with a chronic illness, including asthma. It enables for remote 


\section{Paediatric lung disease}

Figure 2 Study algorithm of (A) the web group, (B) the $\mathrm{FE}_{\mathrm{NO}}$ group and (C) the standard care group. In the web group, patients were asked about adherence to treatment and on signs of airways infection if they returned an Asthma Control Test (ACT) or Childhood ACT (C-ACT) <20. If adherence was poor, or patients had clinical signs of an airway infection (runny nose, fever and malaise), there was no step-up in treatment.
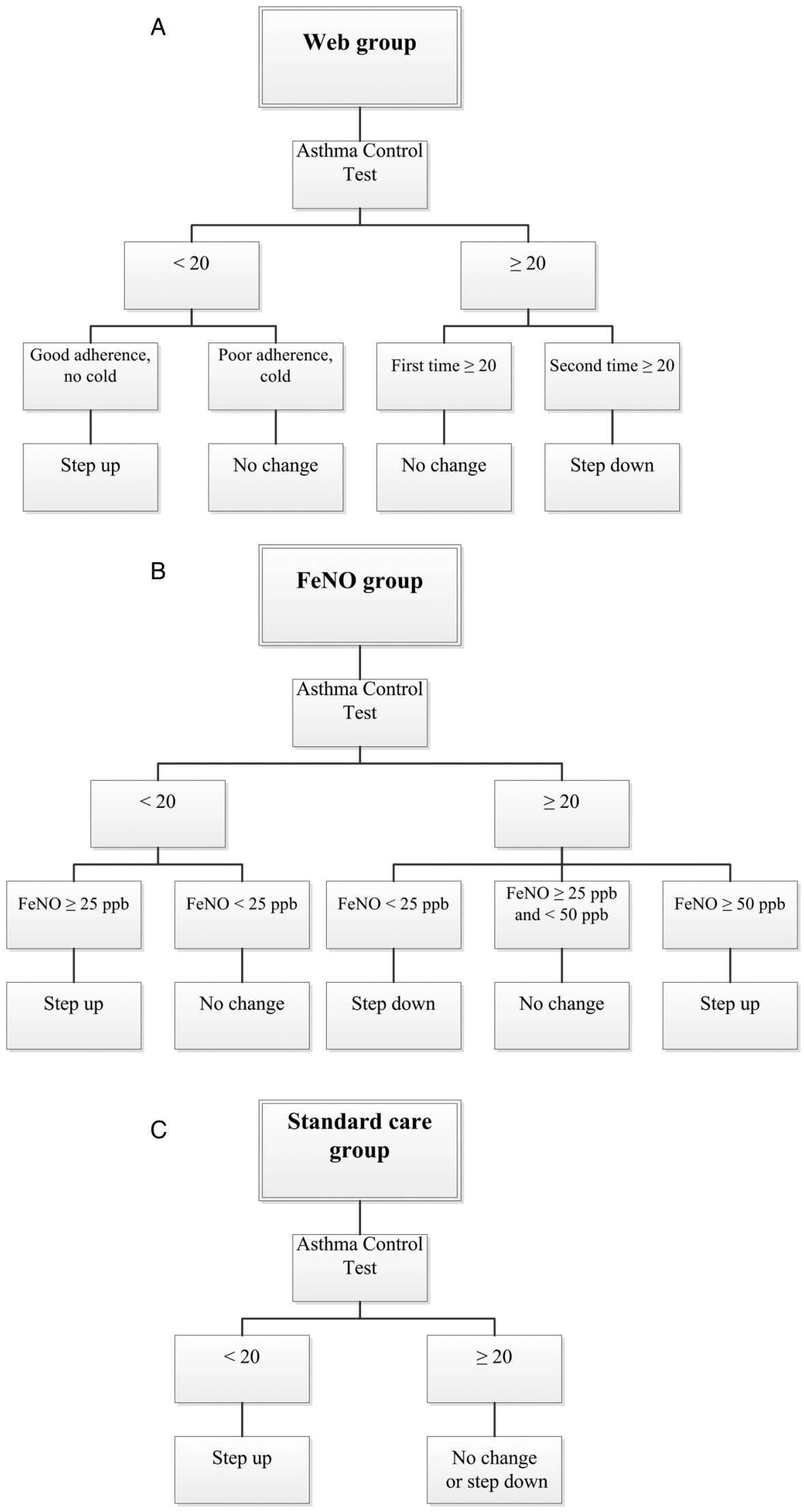

delivery of care, facilitating timely access to healthcare, supporting self-monitoring, medication adherence and education. ${ }^{14-18}$ Earlier studies showed improved lung function, increased adherence, improved asthma control, increased knowledge and improved quality of life after web-based monitoring of asthma compared with SC. ${ }^{19-21}$ We did not find improved asthma control with web-based ACT monitoring. One might argue that baseline ACT, PAQLQ and lung function were higher in the web group than in the SC group, suggesting that the children in the web group had better controlled asthma. Hence, they may have 


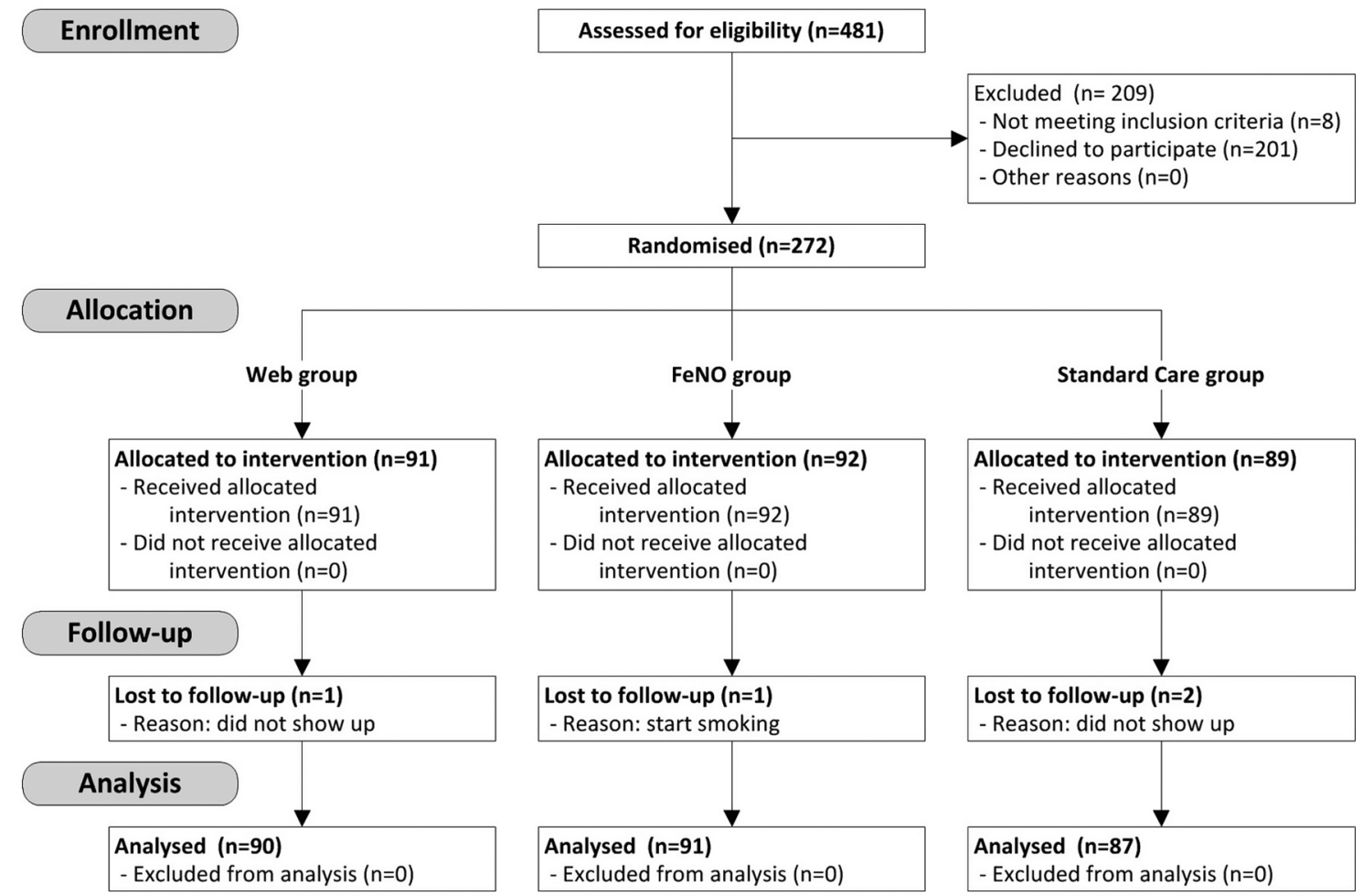

Figure 3 Patient flow according to CONSORT guidelines. A total of 481 children were approached to participate in the study, of which 201 refused. A total of eight children could not be randomised. In the web group, one dropped out; in the $\mathrm{FE}_{\mathrm{No}}$ group, one dropped out; in the standard care group, two children dropped out.

had a greater likelihood of successful ICS reduction. However, the difference between ACT at baseline and the change in ACT from baseline was not significantly different for both groups. This simple strategy halved the dose of ICS, which is substantial, potentially cost-saving and may prevent overtreatment and limit side effects like reduced growth velocity. We did not observe effects on growth: changes in height between the web group and SC group were not significant (data not shown). During the study, $\mathrm{FE}_{\mathrm{NO}}$ increased in the web group when compared with the SC group to a median of $25.2 \mathrm{ppb}$, which is a common value in well-controlled asthma. This might be explained by the decrease in ICS and by regression to the mean.

Table 1 Patient characteristics

\begin{tabular}{|c|c|c|c|c|}
\hline & $\begin{array}{l}\text { Web group } \\
(n=91)\end{array}$ & $\begin{array}{l}\mathrm{FE}_{\mathrm{NO}} \text { group } \\
(\mathrm{n}=92)\end{array}$ & $\begin{array}{l}\text { Standard care } \\
\text { group }(n=89)\end{array}$ & p Value \\
\hline Age (year) & $10.6(2.8)$ & $10.3(2.9)$ & $10.2(3.2)$ & 0.57 \\
\hline Male & $60(66)$ & $62(67)$ & $61(69)$ & 0.94 \\
\hline Height & $145.9(17.0)$ & $144.3(16.2)$ & $141.5(16.6)$ & 0.20 \\
\hline Initial ICS dose, $\mu \mathrm{g}$ & $400 \mu \mathrm{g}(400-800)$ & $400 \mu \mathrm{g}(400-800)$ & $400 \mu \mathrm{g}(400-800)$ & 0.97 \\
\hline LABA use & $42(46)$ & $44(48)$ & $40(45)$ & 0.93 \\
\hline LTRA use & $11(12)$ & $12(13)$ & $11(12)$ & 0.98 \\
\hline $\mathrm{FE}_{\mathrm{NO}}, \mathrm{ppb}$ & $17.1(10.0-30.0)$ & $15.4(10.0-26.3)$ & $21.4(10.5-35.1)$ & 0.64 \\
\hline $\mathrm{FEV}_{1}, \%$ pred & $98.1(12.6)$ & $95.2(12.6)$ & $93.9(14.0)$ & 0.11 \\
\hline FVC, \%pred & $103.3(12.2)$ & $100.3(12.8)$ & $101.0(13.0)$ & 0.29 \\
\hline FEF75, \%pred & $91.0(35.7)$ & $87.3(33.1)$ & $76.0(29.3)$ & 0.01 \\
\hline PD20, $\mu$ g methacholine & $178.5(26.3-738.7)$ & $118.1(41.0-1084.4)$ & $158.2(36.6-379.9)$ & 0.46 \\
\hline ACT or C-ACT score & $22.1(3.5)$ & $20.7(4.3)$ & $21.1(3.3)$ & 0.03 \\
\hline $\mathrm{ACT} \geq 20$ & $73(81)$ & $60(65)$ & $62(70)$ & 0.05 \\
\hline Daily symptom score & $1.1(1.3)$ & $1.4(1.7)$ & $1.3(1.4)$ & 0.26 \\
\hline Daily SABA, puffs & $0.4(0.8)$ & $0.6(1.2)$ & $0.4(0.8)$ & 0.29 \\
\hline Symptom-free days, \% & $60(33)$ & $53(34)$ & $54(35)$ & 0.26 \\
\hline PAQLQ score child & $6.3(5.9-6.6)$ & $6.0(5.6-6.6)$ & $6.2(5.9-6.6)$ & 0.65 \\
\hline PACQLQ score parent & $6.7(6.2-7.0)$ & $6.3(5.7-6.8)$ & $6.1(5.8-6.8)$ & 0.01 \\
\hline
\end{tabular}

Data shown are numbers of patients (\%), mean (SD) or median (IQR).

ACT, asthma control test; C-ACT, Childhood ACT; FEF75, forced expiratory flow at 25\% of vital capacity; ICS, inhaled corticosteroids; LABA, long-acting $\beta$ agonist; LTRA, leukotriene receptor antagonist; PACQLQ, Paediatric Asthma-Related Caregiver Quality of Life Questionnaire; PAQLQ, Paediatric Asthma-Related Quality of Life Questionnaire; PD20, doses of methacholine causing a $20 \%$ fall in $\mathrm{FEV}_{1}$; $\mathrm{SABA}$, short-acting $\beta$ agonist. 
Table 2 Changes from baseline of different outcome parameters

\begin{tabular}{|c|c|c|c|c|c|c|c|}
\hline & $\begin{array}{l}\text { Web } \\
(n=90)\end{array}$ & $\begin{array}{l}\mathrm{FE}_{\mathrm{NO}} \\
(\mathrm{n}=91)\end{array}$ & $\begin{array}{l}\text { Standard care } \\
(\mathrm{n}=87)\end{array}$ & $\begin{array}{l}\text { Difference web versus } \\
\text { standard care } \\
(95 \% \mathrm{Cl})\end{array}$ & p Value & $\begin{array}{l}\text { Difference } \mathrm{FE}_{\mathrm{No}} \text { versus } \\
\text { standard care } \\
(95 \% \mathrm{Cl})\end{array}$ & p Value \\
\hline \multicolumn{8}{|c|}{ Asthma-related symptoms } \\
\hline $\begin{array}{l}\text { SFD, } \% \\
(n=265)\end{array}$ & -2.07 & $8.90 *$ & $7.40^{*}$ & $-6.60(-15.5$ to 2.3$)$ & 0.15 & $1.17(-7.6$ to 10.0$)$ & 0.78 \\
\hline $\begin{array}{l}\text { ACT or C-ACT } \\
(n=269)\end{array}$ & 0.12 & $1.73^{*}$ & 0.37 & $0.09(-0.92$ to 1.11$)$ & 0.86 & $1.19(0.17$ to 2.20$)$ & $0.02^{*}$ \\
\hline $\begin{array}{l}\text { Daily symptom score } \\
(n=264)\end{array}$ & 0.08 & $-0.40^{*}$ & -0.11 & $0.06(-0.34$ to 0.46$)$ & 0.77 & $-0.27(-0.66$ to 0.13$)$ & 0.19 \\
\hline $\begin{array}{l}\text { Limitation of activities } \\
(n=258)\end{array}$ & 0.04 & $-0.09^{*}$ & -0.02 & $0.05(-0.05$ to 0.15$)$ & 0.33 & $-0.05(-0.15$ to 0.05$)$ & 0.34 \\
\hline $\begin{array}{l}\text { Exacerbations } \\
(n=271)\end{array}$ & 10 & 14 & 17 & 7 & 0.07 & 3 & $0.28 t$ \\
\hline \multicolumn{8}{|l|}{ Medication } \\
\hline $\begin{array}{l}\text { SABA use (puffs/day) } \\
(n=270)\end{array}$ & -0.15 & $-0.19 *$ & -0.18 & $-0.01(-0.19$ to 0.18$)$ & 0.93 & $-0.12(-0.30$ to 0.07$)$ & 0.21 \\
\hline $\begin{array}{l}\text { ICS dose }(\mu \mathrm{g}) \\
(\mathrm{n}=270)\end{array}$ & $-201^{*}$ & $-107^{\star}$ & -54 & $-150(-241$ to -60$)$ & $<0.01^{* *}$ & $-53(-144$ to 36$)$ & 0.24 \\
\hline \multicolumn{8}{|l|}{ Lung function (z-score) } \\
\hline $\begin{array}{l}\mathrm{FEV}_{1} \\
(\mathrm{n}=229)\end{array}$ & -0.10 & $0.16^{*}$ & $0.26^{*}$ & $-0.22(-0.46$ to 0.02$)$ & 0.07 & $-0.05(-0.29$ to 0.20$)$ & 0.71 \\
\hline $\begin{array}{l}\text { FVC } \\
(n=229)\end{array}$ & -0.04 & $0.18^{*}$ & $0.22 *$ & $-0.18(-0.38$ to 0.03$)$ & 0.09 & $-0.21(-0.23$ to 0.19$)$ & 0.84 \\
\hline $\begin{array}{l}\text { FEF75 } \\
(n=221)\end{array}$ & -0.20 & 0.09 & 0.16 & $-0.17(-0.44$ to 0.10$)$ & 0.21 & $0.06(-0.21$ to 0.34$)$ & 0.65 \\
\hline $\begin{array}{l}\text { PD20,DD§ } \\
(n=132)\end{array}$ & -0.33 & 0.14 & -0.30 & $-0.06(-1.14$ to 1.00$)$ & 0.92 & $0.43(-0.71$ to 1.58$)$ & 0.46 \\
\hline $\begin{array}{l}\mathrm{FE}_{\mathrm{NO}} \| \\
(\mathrm{n}=266)\end{array}$ & $1.64 \ddagger$ & $1.40 \ddagger$ & $1.18 \ddagger$ & 1.33 (1.09 to 1.62$)$ & $<0.01 * *$ & 1.12 (0.92 to 1.38$)$ & 0.24 \\
\hline \multicolumn{8}{|c|}{ Asthma-related quality of life } \\
\hline $\begin{array}{l}\text { PAQLQ child } \\
(n=89)\end{array}$ & 0.17 & 0.25 & 0.24 & $-0.05(-0.34$ to 0.23$)$ & 0.72 & $-0.13(-0.42$ to 0.15$)$ & 0.36 \\
\hline PACQLQ parent & 0.02 & 0.22 & 0.05 & $0.10(-0.16$ to 0.35$)$ & 0.44 & $0.17(-0.08$ to 0.43$)$ & 0.17 \\
\hline
\end{tabular}

A meta-analysis on 21 randomised controlled trials on telemonitoring interventions in both children and adults with asthma concluded that telemonitoring was comparable with SC regarding quality of life, emergency room visits and hospitalisations for asthma. ${ }^{22} \mathrm{~A}$ recent review on digital asthma selfmanagement interventions concluded that these interventions are promising, with evidence of beneficial effects. ${ }^{23}$ Differences in populations, web-based interventions or frequency of internet contact may account for these discrepancies. The relatively low monitoring frequency in our study might have contributed to the high compliance rates and positive effect. The application of web-based monitoring in childhood asthma management has previously been shown feasible and was well accepted. ${ }^{20} 222425$ In our study, compliance with web-based ACT monitoring was high and patients were generally satisfied with the web-based strategy, in line with earlier studies. ${ }^{24} 25$ Future research should focus on determining which patients will benefit most from web-based interventions, to achieve personalised management.

Several studies addressed titration of ICS treatment on $\mathrm{FE}_{\mathrm{NO}}$ as a marker of eosinophilic inflammation. ${ }^{13} 26-28$ Our primary endpoint, SFD and other markers of asthma control did not improve more with $\mathrm{FE}_{\mathrm{NO}}$ monitoring than with $\mathrm{SC}$. We did observe that $\mathrm{FE}_{\mathrm{NO}}$ monitoring improved the $\mathrm{C}$-ACT scores in children aged from 4 to 11 years with similar doses of ICS as compared with SC. The ACT increase of 1.8 points in this age group is modest but clinically relevant. ${ }^{8}$ A recent systematic review of four paediatric studies showed no differences in exacerbations, symptoms or lung function between $\mathrm{FE}_{\mathrm{NO}}$-based and symptom-based monitoring. ${ }^{6} 7^{26-28}$ In a recent study, $\mathrm{FE}_{\mathrm{NO}}$-guided asthma management did not improve the proportion of SFD, which is in line with our study, but did result in fewer exacerbations. ${ }^{29}$ How does the current study differ from earlier studies? First, we used two $\mathrm{FE}_{\mathrm{NO}}$ cut-off points to define treatment adjustments, in contrast to other $\mathrm{FE}_{\mathrm{NO}}$ dose titration studies, but similar to the study of Szefler et al. ${ }^{26}$ The use of two cut-offs to decrease $(<25 \mathrm{ppb})$ or increase $(>50 \mathrm{ppb})$ the dose of ICS is more in accordance with clinical practice. While $\mathrm{FE}_{\mathrm{NO}}>25 \mathrm{ppb}$ may be abnormal in healthy subjects, in patients with well-controlled asthma, such a value is common, and a growing body of evidence suggests that cut-offs should be based on $\mathrm{FE}_{\mathrm{NO}}$ levels characteristic of the population of interest. ${ }^{30}$ In our study population, children with well-controlled asthma had a median $\mathrm{FE}_{\mathrm{NO}}$ level of $25 \mathrm{ppb}$ (IQR 16-47). Therefore, a cut-off of $25 \mathrm{ppb}$ might not be optimal to increase the dose of 
ICS in asthmatic children. Several studies have shown that $50 \mathrm{ppb}$ seems more appropriate. ${ }^{31}$ Second, in our study, we could decrease ICS when $\mathrm{FE}_{\mathrm{NO}}$ values were low, while most earlier studies did not allow for this. Third, and probably most important, the treatment algorithms based on $\mathrm{FE}_{\mathrm{NO}}$ and SC differed substantially: taking $\mathrm{FE}_{\mathrm{NO}}$ into account led to a different treatment decision at five of the eight possible treatment changes (discordance-concordance ratio 1.7). ${ }^{32}$ In our study, including $\mathrm{FE}_{\mathrm{NO}}$ in the treatment algorithm had actually influenced $62 \%$ of all treatment decisions.

Unexpectedly, only the younger children appeared to have benefit from the $\mathrm{FE}_{\mathrm{NO}}$ strategy. One might speculate that overestimation of asthma control by the parents may play a role and that $\mathrm{FE}_{\mathrm{NO}}$ helps to assess asthma control more objectively. ${ }^{33}$

Are our findings generalisable to general paediatric asthma care? Almost half of all eligible children refused to participate in the study, which may limit the conclusions due to selection bias. However, these children did not differ from included children regarding baseline characteristics. A limitation might be bias due to the required internet access. However, more than $95 \%$ of Dutch households have internet access at home, and only a single eligible child was excluded for this reason.

In conclusion, we have shown that web-based monitoring with monthly ACT or 4-monthly $\mathrm{FE}_{\mathrm{NO}}$ in children with asthma was feasible but did not improve SFD, our primary outcome. Web-based monitoring led to a significant and clinically relevant reduction in ICS dose with similar asthma control, suggesting better, personalised asthma management. $\mathrm{FE}_{\mathrm{NO}}$ monitoring modestly improved asthma control selectively in children aged $<12$ years without the need for higher ICS doses. We hypothesise that a combined strategy of web visits in combination with $\mathrm{FE}_{\mathrm{NO}}$ measurements during clinic visits may be a superior strategy to monitor children with asthma, and this should be tested in future studies.

\section{Author affiliations \\ 'Department of Paediatrics, Division Paediatric Respiratory Medicine, Erasmus University Medical Centre-Sophia Children's Hospital, Rotterdam, the Netherlands ${ }^{2}$ Department of Paediatrics, Amphia Hospital, Breda, the Netherlands ${ }^{3}$ Department of Paediatrics, Catharina Hospital, Eindhoven, the Netherlands ${ }^{4}$ Department of Paediatrics, Rijnstate Hospital, Arnhem, the Netherlands ${ }^{5}$ Department of Paediatrics, Flevo Hospital—De Kinderkliniek, Almere, the Netherlands \\ ${ }^{6}$ Department of Biostatistics, Erasmus University Medical Centre, Rotterdam, the Netherlands \\ ${ }^{7}$ Department of Paediatric Pulmonology, Radboud University Medical Centre, Nijmegen, the Netherlands}

Acknowledgements We gratefully thank the involved paediatricians, paediatric asthma nurses and lung function technicians for their help and active guidance throughout the study: Simone Suelmann, Hannie Achterberg, Bas Harzing, Dorine de Hond, Saskia ten Raa (Amphia Hospital), Coosje Sintnicolaas, Cindy Hugen, Jessie Jacobs, Petra Theissen (Radboud University Medical Center), Christel Linssen, Martin Claassens (Catharina Hospital), Linda van Gilst, Gracé Theunissen, Mark Holewijn, Annejet Plaisier (Rijnstate Hospital), Renata de Ridder, Else Stoter (De Kinderkliniek), Prof. Wim van Aalderen, Saeeda Lone and Erik-Jonas van de Griendt (Amsterdam Medical Center).

Contributors SV-VB, JCdJ and MWP: Operated as a writing committee and drafted the manuscript until it reached its final form. SV-vB, AAV-V, HJB, AML, NJvdB, PJM, MWP and JCdJ: All participated as investigators in this trial, recruited patients, performed the treatments and commented on the manuscript and its revisions. SV-vB and WCH: Performed the statistical analysis.

Funding This study was funded by Lung foundation Netherlands (grant no 3.4.08.039), the Netherlands Organization for Health Research (ZonMW) (grant no 171002101), and Fund Nuts Ohra (grant no 0901-023).

Competing interests None declared.
Ethics approval Medical Ethics Committee of the Erasmus University Medical Centre, Rotterdam.

Provenance and peer review Not commissioned; internally peer reviewed.

\section{REFERENCES}

1 Gustafsson PM, Watson L, Davis KJ, et al. Poor asthma control in children: evidence from epidemiological surveys and implications for clinical practice. Int I Clin Pract 2006;60:321-34.

2 GINA. Global Strategy for Asthma Management and Prevention. Global Initiative for Asthma (GINA), 2011.

3 National Asthma Education and Prevention Program. Expert Panel Report 3 (EPR-3): Guidelines for the Diagnosis and Management of Asthma-Summary Report 2007. J Allergy Clin Immunol 2007;120(5 Suppl):S94-138.

4 Liu AH, Zeiger R, Sorkness C, et al. Development and cross-sectional validation of the Childhood Asthma Control Test. J Allergy Clin Immunol 2007;119:817-25.

5 Nathan RA, Sorkness CA, Kosinski M, et al. Development of the asthma control test: a survey for assessing asthma control. J Allergy Clin Immunol 2004;113:59-65.

6 Pijnenburg MW, De Jongste JC. Exhaled nitric oxide in childhood asthma: a review. Clin Exp Allergy 2008;38:246-59.

7 Petsky HL, Cates CJ, Li A, et al. Tailored interventions based on exhaled nitric oxide versus clinical symptoms for asthma in children and adults. Cochrane Database Syst Rev 2009;(4):CD006340.

8 Voorend-van Bergen S, Vaessen-Verberne AA, Landstra AM, et al. Monitoring childhood asthma: Web-based diaries and the asthma control test. J Allergy Clin Immunol 2014;133:1599-605.e2.

9 Quanjer PH, Stanojevic S, Cole TJ, et al. Multi-ethnic reference values for spirometry for the 3-95-yr age range: the global lung function 2012 equations. Eur Respir J 2012;40:1324-43.

10 American Thoracic Society, European Respiratory Society. ATS/ERS recommendations for standardized procedures for the online and offline measurement of exhaled lower respiratory nitric oxide and nasal nitric oxide, 2005. Am J Respir Crit Care Med 2005;171:912-30.

11 Juniper EF, Guyatt $\mathrm{GH}$, Feeny $\mathrm{DH}$, et al. Measuring quality of life in children with asthma. Qual Life Res 1996;5:35-46.

12 Raat $\mathrm{H}$, Bueving $\mathrm{HJ}$, de Jongste JC, et al. Responsiveness, longitudinal- and cross-sectional construct validity of the Pediatric Asthma Quality of Life Questionnaire (PAQLQ) in Dutch children with asthma. Qual Life Res 2005; 14:265-72.

13 Pijnenburg MW, Bakker EM, Hop WC, et al. Titrating steroids on exhaled nitric oxide in children with asthma: a randomized controlled trial. Am J Respir Crit Care Med 2005;172:831-6.

14 Van Gaalen JL, Hashimoto S, Sont JK. Telemanagement in asthma: an innovative and effective approach. Curr Opin Allergy Clin Immunol 2012:12:235-40.

15 Meystre $S$. The current state of telemonitoring: a comment on the literature. Telemed J E Health 2005;11:63-9.

16 Ekeland AG, Bowes A, Flottorp S. Methodologies for assessing telemedicine: a systematic review of reviews. Int J Med Inform 2012;81:1-11.

17 Ekeland AG, Bowes A, Flottorp S. Effectiveness of telemedicine: a systematic review of reviews. Int J Med Inform 2010;79:736-71.

18 Jaana $M$, Pare G, Sicotte $C$. Home telemonitoring for respiratory conditions: a systematic review. Am J Manag Care 2009;15:313-20.

19 Rasmussen LM, Phanareth K, Nolte $\mathrm{H}$, et al. Internet-based monitoring of asthma: a long-term, randomized clinical study of 300 asthmatic subjects. J Allergy Clin Immunol 2005;115:1137-42.

20 Jan RL, Wang JY, Huang MC, et al. An internet-based interactive telemonitoring system for improving childhood asthma outcomes in Taiwan. Telemed J E Health 2007;13:257-68.

21 Chan DS, Callahan CW, Hatch-Pigott VB, et al. Internet-based home monitoring and education of children with asthma is comparable to ideal office-based care: results of a 1-year asthma in-home monitoring trial. Pediatrics 2007;119:569-78.

22 McLean S, Chandler D, Nurmatov U, et al. Telehealthcare for asthma: a Cochrane review. CMAJ 2011;183:E733-42.

23 Morrison D, Wyke S, Agur K, et al. Digital asthma self-management interventions: a systematic review. J Med Internet Res 2014;16:e51.

24 Deschildre A, Beghin L, Salleron J, et al. Home telemonitoring (forced expiratory volume in $1 \mathrm{~s}$ ) in children with severe asthma does not reduce exacerbations. Eur Respir J 2012;39:290-6.

25 Koolen BB, Pijnenburg MW, Brackel HJ, et al. Validation of a web-based version of the asthma control test and childhood asthma control test. Pediatr Pulmonol 2011:46:941-8

26 Szefler SJ, Mitchell H, Sorkness CA, et al. Management of asthma based on exhaled nitric oxide in addition to guideline-based treatment for inner-city 


\section{Paediatric lung disease}

adolescents and young adults: a randomised controlled trial. Lancet 2008:372:1065-72.

27 Fritsch M, Uxa S, Horak F Jr, et al. Exhaled nitric oxide in the management of childhood asthma: a prospective 6-months study. Pediatr Pulmonol 2006;41:855-62.

28 de Jongste JC, Carraro S, Hop WC, et al. Daily telemonitoring of exhaled nitric oxide and symptoms in the treatment of childhood asthma. Am J Respir Crit Care Med 2009:179:93-7.

29 Peirsman EJ, Carvelli TJ, Hage PY, et al. Exhaled nitric oxide in childhood allergic asthma management a randomised controlled trial. Pediatr Pulmonol 2014;49:624-31.
30 Barnes PJ, Dweik RA, Gelb AF, et al. Exhaled nitric oxide in pulmonary diseases: a comprehensive review. Chest 2010;138:682-92.

31 Dweik RA, Boggs PB, Erzurum SC, et al. An official ATS clinical practice guideline: interpretation of exhaled nitric oxide levels ( $\mathrm{FE}_{\mathrm{NO}}$ ) for clinical applications. Am J Respir Crit Care Med 2011;184:602-15.

32 Gibson PG. Using fractional exhaled nitric oxide to guide asthma therapy: design and methodological issues for ASthma TReatment ALgorithm studies. Clin Exp Allergy 2009:39:478-90.

33 Voorend-van Bergen S, Brackel H, Caudri D, et al. Assessment of asthma control by children and parents. Eur Respir J 2013;41:233-4. 